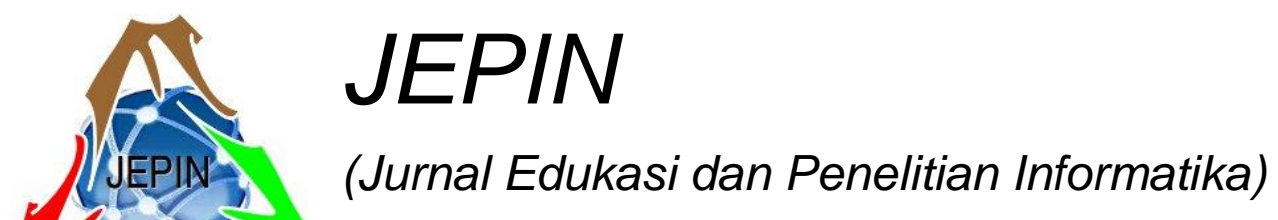

Vol. 6

No. 3

Desember

ISSN(e): 2548-9364 / ISSN(p) : 2460-0741

2020

\title{
Implementasi Chatbot Pembelajaran Bahasa Inggris menggunakan Media Sosial
}

\author{
Moechammad Sarosa $^{\# 1}$, Achmad Suyono ${ }^{* 2}$, Mila Kusumawardani ${ }^{\# 3}$, Zamah Sari ${ }^{+4}$ \\ \#Jurusan Teknik Elektro, Politeknik Negeri Malang \\ ${ }^{1}$ msarosa@polinema.ac.id \\ 3 mila.kusumawardani@polinema.ac.id \\ *Jurusan Administrasi Niaga, Politeknik Negeri Malang \\ 2achmad.suyono@polinema.ac.id \\ ${ }^{+}$Jurusan Informatika, Universitas Muhammadiyah Malang \\ 4zamahsari@umm.ac.id
}

\begin{abstract}
Abstrak - Bagi sebagian kalangan belajar bahasa Inggris adalah sesuatu yang tidak mudah sehingga perlu pendamping untuk memperbaiki jika terjadi kesalahan. Belajar bahasa Inggris bisa diawali dengan memahami secara benar strukturnya sehingga dapat membantu dan memberikan rasa percaya ciri saat mempelajari materimateri selanjutnya seperti reading, listening maupun writing. Penelitian ini bertujuan mengembangkan suatu aplikasi chatbot untuk belajar struktur bahasa Inggris menggunakan media sosial. Pertimbangan utama penggunaan media sosial sebagai sarana pembelajaran yaitu sebagian besar aktifitas masyarakat hingga pelajar di musim pandemic ini menggunakan media sosial atau sarana belajar berbasis online, sehingga dirasa bahwa media sosial bukan sesuatu yang baru bagi khalayak ramai dan menjadi alternatif terbaik yang dapat digunakan sebagai sarana untuk menyampaikan materi struktur bahasa Inggris. Facebook dengan fasilitas chatfuel-nya digunakan untuk mengembangkan chatbot pembelajaran struktur bahasa Inggris dengan memanfaatkan metode Organization Exercise Items (OEI). Dengan menggunakan metode OEI maka chatbot secara otomatis akan memberikan bantuan apabila ada seseorang yang sedang belajar mengalami kesulitan. Aplikasi yang diberi nama ELA-bot atau English Learning Assistant Bot ini telah diimplementasikan pada mahasiswa program studi D3 Bahasa Inggris, Politeknik Negeri Malang. Hasil pengujian menunjukkan bahwa $97,5 \%$ mahasiswa menyatakan chatbot telah membantu dalam proses pembelajaran struktur Bahasa inggris.
\end{abstract}

Kata kunci-Chatbot, Media Sosial, Pembelajaran, struktur Bahasa Inggris, Organization Exercise Items

\section{Pendahuluan}

Secara umum, chatbot adalah program komputer yang dapat melakukan tugas otomatis, dan dapat berfungsi di platform pengiriman pesan [1]. Chatbots meniru percakapan manusia dengan menggunakan Artificial
Intelligence (AI) [2] [3] [4]. Chatbot adalah agen percakapan otomatis yang berinteraksi dengan pengguna menggunakan bahasa alami manusia yang dapat membantu kapan saja dan dimana saja [5] [6] [7] [8]. Saat ini, dengan perkembangan kecerdasan buatan, chatbots digunakan diberbagai bidang, seperti sistem penjawab telepon otomatis, dukungan pendidikan, bisnis, e-commerce, asisten virtual utama, tujuan hiburan, membantu seseorang menyelesaikan tugas mulai dari menjawab pertanyaan, memberikan petunjuk arah mengemudi, menyalakan termostat di rumah pintar, dan memainkan lagu favorit [2] [6] [9]. Baru-baru ini, chatbot telah mendapat banyak perhatian dari para peneliti, menunjukkan bahwa banyak penelitian telah dilakukan, seperti chatbot untuk menjawab Frequently Asked Questions (FAQ), aplikasi chatbot untuk pendidikan, atau evaluasi platform chatbot [6] [10].

Chatbots adalah sebuah aspek positif yang sudah lama digunakan sebagai agen pedagogis dalam pengaturan pendidikan [5] [11] [12]. Sejak awal 1970-an, agen pedagogis dalam lingkungan pembelajaran digital yang dikenal sebagai Sistem Bimbingan Cerdas telah dikembangkan. Agen pedagogis percakapan menggunakan teknik kecerdasan buatan untuk meningkatkan otomatisasi dalam pengajaran [13]. Pengetahuan desain dan penelitian penting dalam mengembangkan agen pedagogis yang menarik dan berguna yang tidak hanya memanfaatkan kemajuan teknologi, tetapi juga memahami masalah emosional, kognitif, dan pendidikan sosial. Selain itu, agen percakapan telah dibangun ke dalam perangkat lunak dan perangkat keras [11].

Penggabungan chatbot ke dalam area pendidikan selama dekade terakhir menyiratkan peningkatan minat terhadap cara-cara penerapan chatbot untuk pengajaran dan pembelajaran [14]. Sistem chatbot yang berguna dapat memberikan manfaat ketersediaan dengan instan dan 
kemampuan untuk merespons secara alami melalui antarmuka percakapan dengan keuntungan yang sama seperti wawancara. Selain itu, chatbot mendemonstrasikan kemampuan untuk menciptakan interaksi dengan pengguna sehingga dapat dimanfaatkan untuk mendukung keterlibatan, serta menetapkan tujuan, strategi, dan hasil pembelajaran dan pelatihan. Salah satu aplikasi chatbot yang digunakan dalam bidang pendidikan yaitu untuk pembelajaran bahasa Inggris [11].

Saat ini, pentingnya bahasa Inggris di dunia tidak dapat disangkal dan diabaikan karena bahasa Inggris adalah bahasa yang paling umum digunakan. Bahasa Inggris membantu dalam mengembangkan teknologi [15]. Bahasa Inggris telah memiliki peran yang penting pada sektor Pendidikan. Beberapa tempat pembelajaran bahasa Inggris melatih guru untuk memberikan teknik pembelajaran baru [16].

Perkembangan teknologi dan gaya hidup memungkinkan pembelajaran baru bahasa Inggris yang dilakukan secara online (chat) melalui media sosial. Komunikasi bisa dalam bentuk teks (text chat) atau suara (voice chat) sehingga seolah-olah pengguna sedang berbicara dengan tutor. Keunggulan sistem ini adalah pengguna yang perlu berlatih bahasa Inggris dapat dilayani hampir 24 jam sehari sehingga tidak ada mendukung potensi interaksi siswa ke siswa dan siswa ke instruktur dengan menggunakan jejaring sosial Facebook [17]. Penelitian sebelumnya juga menyimpulkan bahwa praktik mengajar berbasis gamifikasi meningkatkan sikap siswa terhadap pelajaran dan berpengaruh positif terhadap prestasi belajar siswa [18]. Facebook adalah perusahaan teknologi yang deploy platform untuk mengembangkan chatbot dengan kemampuan bahasa alami [19].

Implementasi yang cepat dari platform framework berbasis cloud untuk chatbot dikarenakan kesederhanaannya. Chatfuel merupakan framework pembuat chatbot yang telah digunakan oleh beberapa perusahaan kelas dunia karena chatbot yang dibuat oleh Chatfuel hanya membutuhkan waktu yang singkat dalam menjawab pertanyaan dari banyak pengguna sekaligus [11]. Chatfuel menyediakan platform online yang memungkinkan pengguna membuat chatbot untuk Facebook Messenger melalui antarmuka visual yang mudah digunakan [20] [21].

Pada penelitian ini dibuat aplikasi berupa chatbot atau robot penjawab sebagai pengganti guru yang diimplementasikan pada pelajar atau mahasiswa untuk membantu belajar Bahasa inggris apabila mengalami kesulitan. Aplikasi chatbot terintegrasi dengan media sosial Facebook yang dinamakan ELA-bot menggunakan framework Chatfuel.

\section{METODE}

Mekanisme dasar chatbot dimulai dengan pesan yang dikirim oleh pengguna. Pesan tersebut kemudian diproses oleh NLP (Natural Language Processing), dan chatbot merespons dengan membalas pesan tersebut [22]. Tahapan proses chat ditampilkan pada Gambar 1.

Rancangan chatbot dimulai dengan masukan teks dari pengguna menggunakan Facebook Messenger. Pada Chatfuel Chatbot builder, administrator sebelumnya telah menentukan respon chatbot menggunakan Natural Language Processing (NLP) dan sistem pakar forward chaining. Teknologi NLP memungkinkan kamus dapat tersusun lebih baik. Kemudian AI Rule Block diterapkan sesuai NLP dan sistem pakar untuk menyajikan materi. Sedangkan Organization Exercise Items (OEI) digunakan untuk menentukan level pertanyaan pada latihan soal sesuai dengan skor yang diperoleh pengguna [23]. Metode urutan pertanyaan yang sesuai berdasarkan tingkat kompetensi pengguna kemudian dipilih dan disortir.

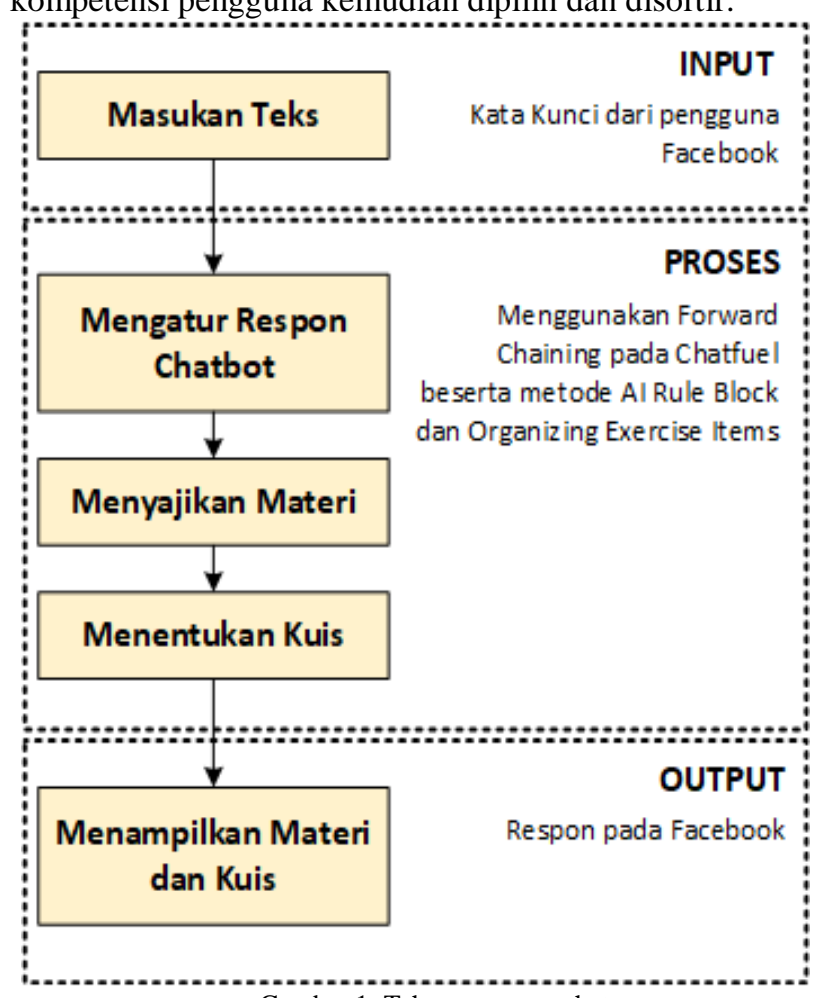

Gambar 1. Tahapan proses chat

Pada tahap analisis, semua kebutuhan yang terkait dengan pembangunan dan pengembangan chatbot harus terpenuhi agar dapat diterima oleh pengguna. Pembuatan antarmuka aplikasi menggunakan Chatfuel Chatbot builder [11] [24].

$$
\text { materi ke- } i
$$

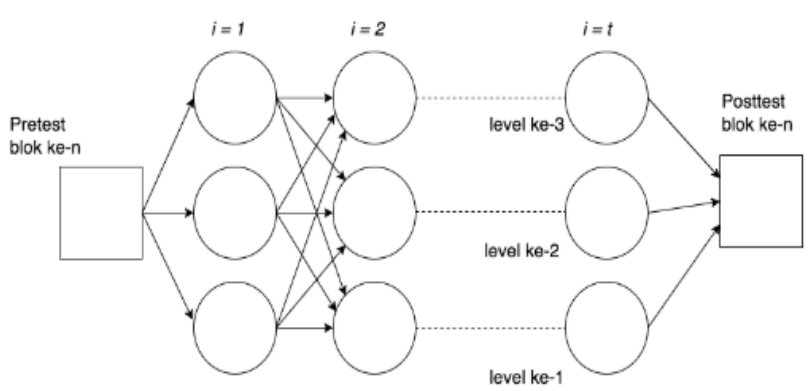

Gambar 2. Alur metode Organization Exercise Items [11] 


\section{A. Use Case Diagram}

Use case diagram adalah diagram yang menggambarkan kebutuhan sistem yang menjelaskan hubungan antara aktor dan use case didalam sistem. Sistem yang dibangun adalah sebuah aplikasi chatbot sebagai pembelajaran bahasa Inggris. Aktor pada sistem ini yaitu administrator dan pengguna. Use case diagram administrator ditampilkan pada Gambar 3 .

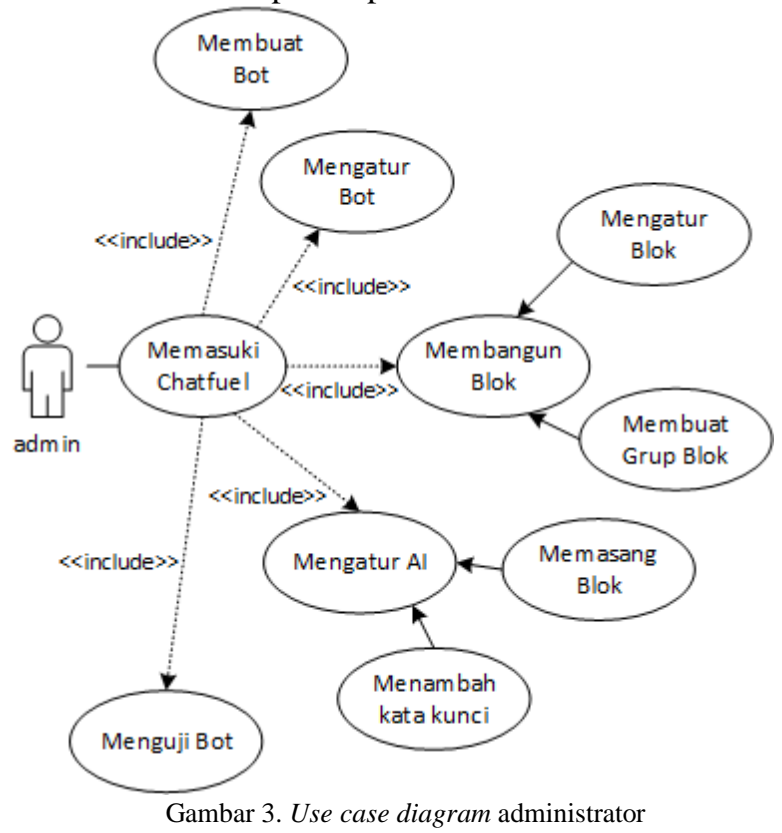

Use case diagram administrator setelah dapat memasuki chatfuel dengan login untuk mendapatkan bot kemudian mengatur bot untuk diuji pada Messenger. Administrator juga dapat membuat bot lain atau mengatur AI dan membangun block yang sudah dibuat sebelumnya. Use case diagram Pengguna ditampilkan pada Gambar 4.

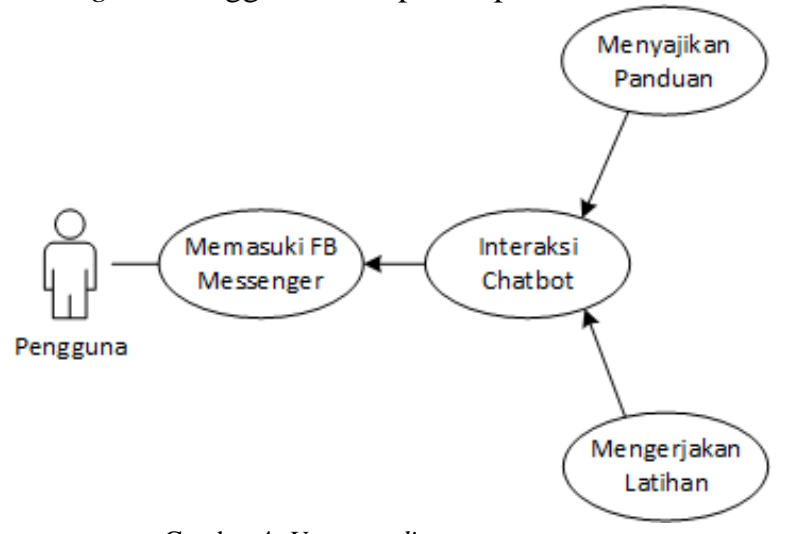

Gambar 4. Use case diagram pengguna

Use case diagram pengguna setelah dapat memasuki Facebook Messenger pengguna dapat berinteraksi dengan chatbot. Pada penelitian ini menggunakan chatbot yang bernama ELA-bot atau English Learning Assistant. Kemudian pengguna bisa mendapatkan panduan dan mengerjakan soal latihan.

\section{B. Framework Chatfuel}

Integrasi antara Facebook Messenger dengan framework Chatfuel. Konsep pembangunan chatbot menggunakan Chatfuel ditampilkan pada Gambar 5. Chatfuel menyediakan dua pilihan untuk membuat chatbot diantaranya dapat menggunakan template yang sudah disediakan. Kemudian membuat halaman Facebook. Halaman Facebook dapat diintegrasikan dengan chatbot pada Chatfuel [25]. Setelah berhasil terhubung, pengaturan AI, menambah grup dan menambah AI rule dapat dilakukan pada Chatfuel. Selanjutnya menambahkan skenario percakapan dengan memasukkan kata kunci dari pengguna serta menambah respon bot sebagai balasan untuk pengguna. Respon bot dapat ditambahkan sesuai kebutuhan, dapat berupa block maupun teks yang sudah selesai dibuat pada proses sebelumnya. Kemudian aplikasi dapat digunakan pada Facebook Messenger.

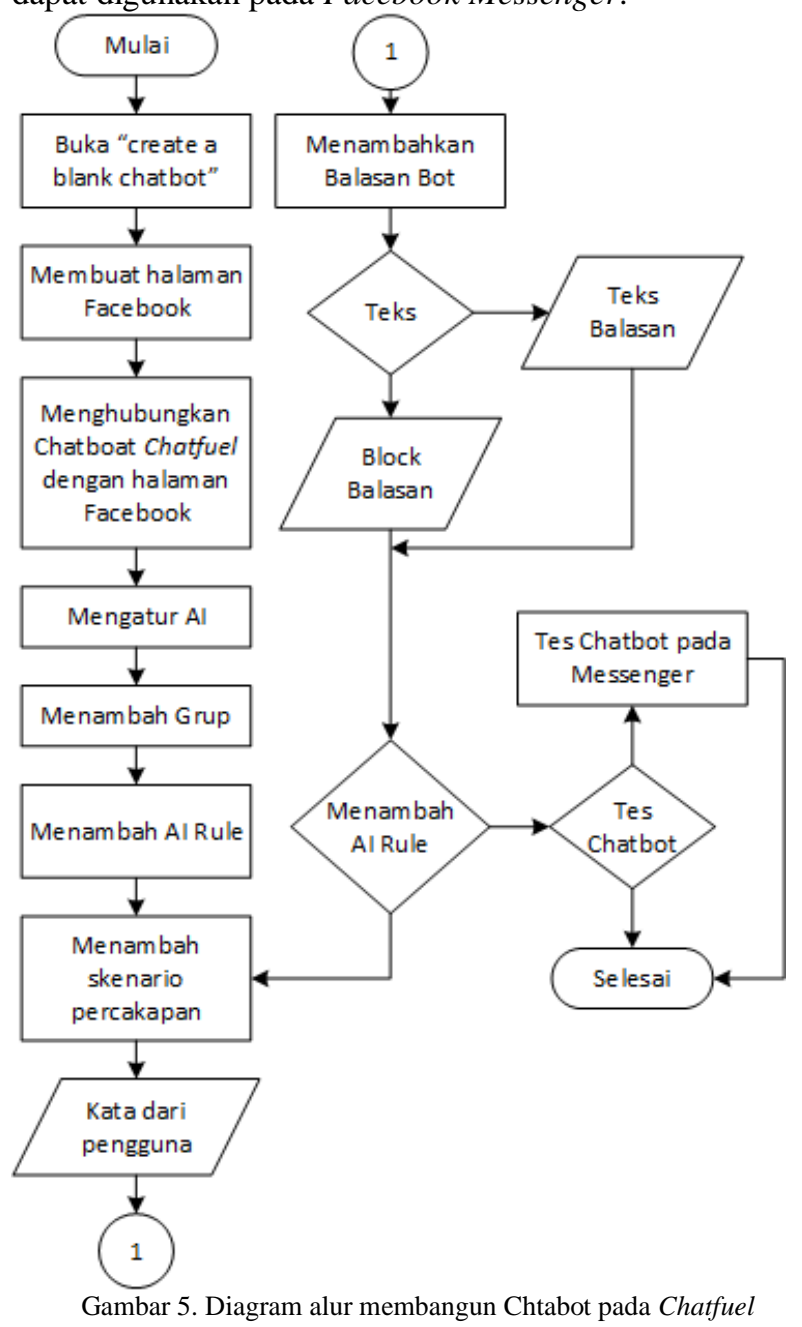

\section{HASIL DAN PEMBAHASAN}

Berdasarkan algoritma yang diterapkan pengguna dapat mengakses Facebook messenger. Kemudian mencari halaman ELA-bot dan menggunakan aplikasi. Halaman ELA-bot ditampilkan pada Gambar 6. Setelah kotak percakapan terbuka, klik tombol start/mulai pada 
percakapan. Respon awal ELA-bot berisi salam yang disertai nama pengguna yang login dan perintah untuk memilih antara membuka panduan atau langsung berlatih dengan klik tombol masing-masing pilihan. Seperti yang ditampilkan pada Gambar 7.

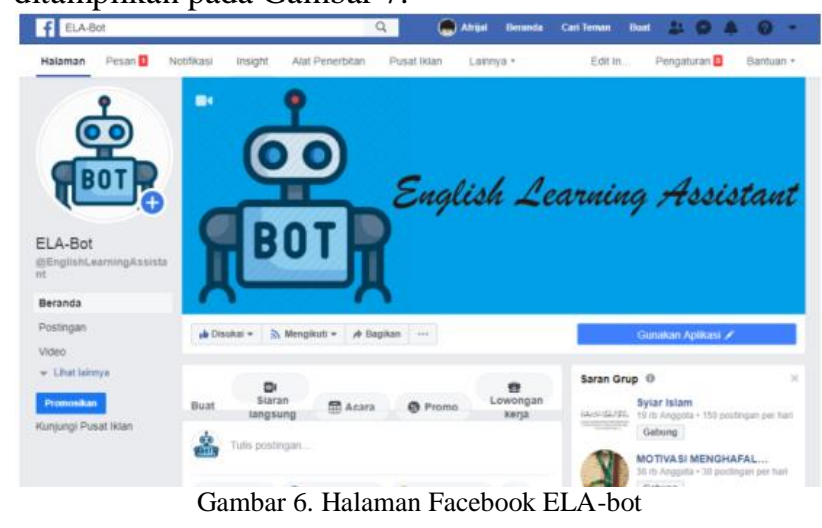

\section{ELA-Bot}

\subsection{9}

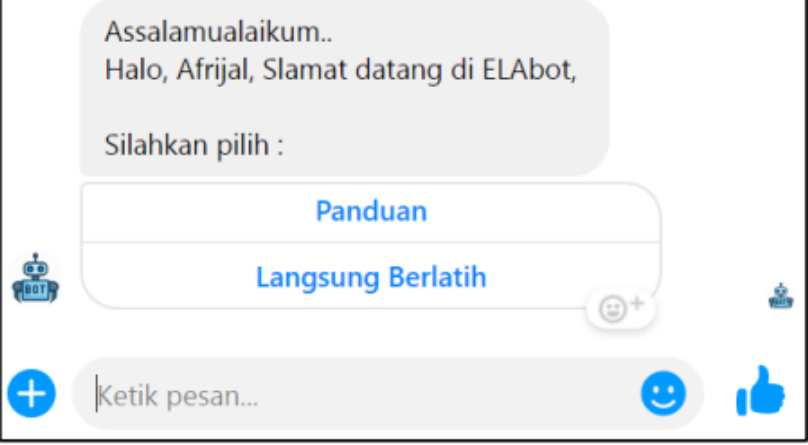

Gambar 7. Respon awal ELA-bot

Panduan berlatih seperti yang ditampilkan pada Gambar 8 dan pilihan untuk memulai berlatih seperti yang ditampilkan pada Gambar 9. Latihan terdapat pilihan untuk memilih kategori. Kemudian soal-soal latihan yang harus dijawab akan ditampilkan.

Panduan seperti yang ditampilkan pada Gambar 8, berisi penejelasan untuk memilih salah satu kategori latihan soal, pengguna mendapatkan soal dengan level sesuai dengan kategori yang dipilih, panduan untuk memilih jawaban yang tepat, dan pemberitahuan apabila selesai mengerjakan latihan maka hasil skor latihan akan muncul. Jika hasil skor lebih dari atau sama dengan 80, maka pengguna masuk kategori level up dan jika hasil skor kurang dari 40, maka pengguna masuk kategori level drop.

Ketika pengguna memilih tombol "langsung berlatih" seperti yang ditampilkan pada Gambar 9, pada tampilan muncul percakapan untuk memilih kategori, contohnya kategori "vocabulary". Setelah memilih kategori maka akan muncul latihan soal yang harus dijawab seperti yang ditampilkan pada Gambar 10.
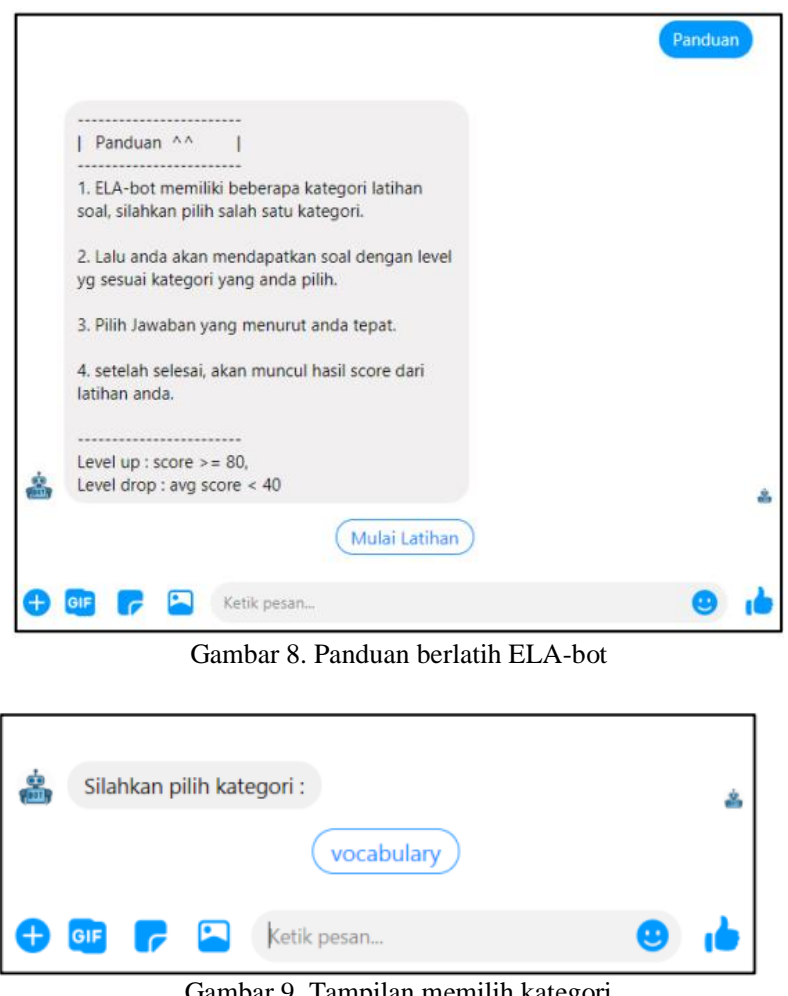

Gambar 9. Tampilan memilih kategori

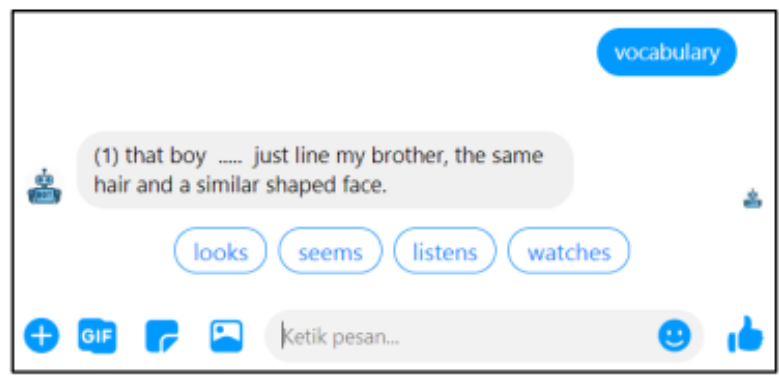

Gambar 10. Latihan soal yang harus dijawab

Pada Gambar 10 menampilkan bentuk latihan soal dari kategori "vocabulary". Tipe latihan soal yaitu berupa multiple choice. Setelah semua soal telah selesai terjawab, akan muncul hasil skor dari latihan yang dikerjakan seperti yang ditampilkan pada Gambar 11.

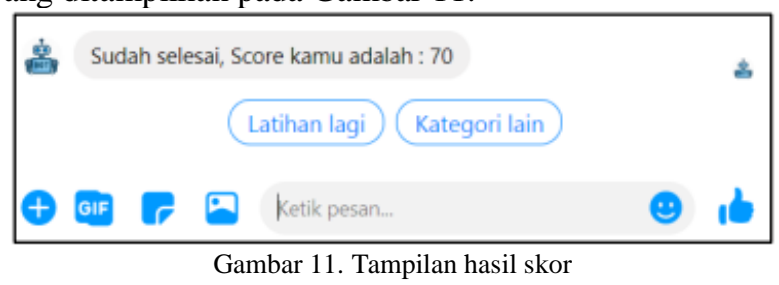

Berdasarkan Gambar 11, pengguna dapat mnengetahui skor dari hasil latihan soal yang telah dijawab. Setelah muncul skor hasil, pengguna dapat memilih untuk latihan 
lagi dengan kategori yang sama dengan menekan tombol "latihan lagi". Jika pengguna ingin melakukan latihan lagi dengan kategori yang berbeda, pengguna dapat menekan tombol "Kategori lain".

Aplikasi ELA-bot atau English Learning Assistant telah diimplementasikan pada mahasiswa Program Studi D3 Bahasa Inggris, Politeknik Negeri Malang yang berjumlah 40 orang. Terdapat tiga penilaian pada kuesioner yang ditampilkan pada Tabel 1.

TABEL I

PENGUJIAN KUESIONER

\begin{tabular}{|c|c|c|c|}
\hline No. & Pertanyaan & \multicolumn{2}{|c|}{ Tanggapan } \\
\hline 1. & $\begin{array}{l}\text { Apakah chatbot } \\
\text { telah membantu } \\
\text { untuk belajar } \\
\text { bahasa Inggris? }\end{array}$ & Membantu & $\begin{array}{c}\text { Tidak } \\
\text { Membantu }\end{array}$ \\
\cline { 2 - 4 } 2. & $\begin{array}{l}\text { Apakah materi } \\
\text { yang disajikan } \\
\text { cukup menarik? }\end{array}$ & Menarik & $\begin{array}{c}\text { Tidak } \\
\text { Menarik }\end{array}$ \\
\hline 3. & $\begin{array}{l}\text { Apakah aplikasi } \\
\text { chatbot } \\
\text { membebani } \\
\text { kinerja } \\
\text { handphone } \\
\text { mahasiswa? }\end{array}$ & Membebani & $\begin{array}{c}\text { Tidak } \\
\text { Membebani }\end{array}$ \\
\cline { 3 - 4 } & & 11 & 29 \\
\hline
\end{tabular}

Berdasarkan Tabel 1, Dapat diperoleh presentase respon mahasiswa terhadap aplikasi chatbot seperti yang ditampilkan pada persamaan (1), (2), dan (3).

Pertanyaan ke-1 $=(39 \div 40) \times 100 \%=97,5 \%$

Pertanyaan ke- $2=(36 \div 40) \times 100 \%=90 \%$

Pertanyaan ke-3 $=(29 \div 40) \times 100 \%=72,5 \%$ Sehingga dapat diketahui $97,5 \%$ menyatakan chatbot telah membantu mereka belajar bahasa Inggris, 90\% menyampaikan bahwa materi yang disajikan cukup menarik dan $72,4 \%$ menyatakan aplikasi chatbot tidak membebani kinerja handphone mereka.

\section{KESIMPULAN}

ELA-bot atau English learning Assistant adalah suatu aplikasi yang pembelajaran dengan memberikan respon percakapan pada pengguna. Aplikasi ini terdapat latihan soal dengan materi kosakata. Soal latihan yang didapatkan pengguna yaitu berdasarkan skor yang diperoleh dari latihan sebelumnya. Berdasarkan hasil analisis ELA-bot mampu menjawab pertanyaan dengan tepat sesuai skor dan penyajian materi menggunakan messenger dengan metode Organizing Exercise Items (OEI). Aplikasi ini telah dilakukan uji coba pada mahasiswa D3, Program Studi Bahasa Inggris, Politeknik Negeri Malang. Hasil pengujian menunjukkan bahwa 97,5\% menyatakan bahwa chatbot telah membantu mereka belajar bahasa Inggris, 90\% menyampaikan bahwa materi yang disajikan cukup menarik dan $72,5 \%$ aplikasi chatbot tidak membebani kinerja handphone mereka. Hal ini menunjukkan bahwa koleksi informasi dan model bantuan pengorganisasian latihan soal yang ada dalam aplikasi telah membantu mahasiswa belajar bahasa Inggris secara mandiri.

\section{UCAPAN TERIMA KASIH}

Penelitian ini didukung oleh Direktorat Jenderal Pendidikan Tinggi, Indonesia melalui hibah Penelitian Terapan Unggulan Perguruan Tinggi (PTUPT).

\section{REFERENCES}

[1] N. A. Ahmad, M. H. C. Hamid, A. Zainal, M. F. A. Rauf and Z. Adnan, "Review of Chatbots Design Techniques," International Journal of Computer Applications, vol. 181, no. 8, pp. 7-10, August 2018.

[2] B. R. Ranoliya, N. Raghuwanshi and S. Singh, "Chatbot for university related FAQs," in International Conference on Advances in Computing, Communications and Informatics (ICACCI), Udupi, 2017.

[3] G. Molnár and Z. Szüts, "The Role of Chatbots in Formal Education," in 2018 IEEE 16th International Symposium on Intelligent Systems and Informatics (SISY), Subotica, 2018.

[4] R. Dale, "The return of the chatbots," Natural Language Engineering, vol. 22, no. 5, pp. 811-817, September 2016.

[5] A.-A. Georgescu, "Chatbots for Education - Trends, Benefits and Challenges," in eLearning and Software for Education (eLSE), 2018.

[6] X. L. Pham, T. Pham, Q. M. Nguyen, T. H. Nguyen and T. T. H. Cao, "Chatbot as an Intelligent Personal Assistant for Mobile Language Learning," in Proceedings of the 2018 2nd International Conference on Education and E-Learning , 2018.

[7] D. Zumstein and S. Hundertmark, "Chatbots -An Interactive Technology for Personalized Communication, Transactions and Services," IADIS International Journal on WWW/Internet, vol. 15, no. 1, pp. 96-109, January 2017.

[8] P. B. Brandtzaeg and A. Følstad, "Why People Use Chatbots," in International Conference on Internet Science, 2017.

[9] L. Cui, S. Huang, F. Wei, C. Tan and C. Duan, "Superagent: A customer service chatbot for e-commerce websites," in Proceedings of ACL System Demonstrations (pp. 97-102)., Vancouver, Canada, 2017.

[10] J. Saenz, W. Burgess, E. Gustitis and A. Mena, "The usability analysis of chatbot technologies for internal personnel communications," in Institute for Industrial and Systems Engineers Annual Conference \& Expo (IISE), (pp. 1357-1362)., Pittsburgh, Pennsylvania, USA, 2017.

[11] M. Sarosa, M. Kusumawardani, A. Suyono and M. H. Wijaya, "Developing a social media-based Chatbot for English learning," in The 1st Annual Technology, Applied Science, and Engineering Conference, Malang, 2020.

[12] . O. Zahour, E. H. Benlahmar, A. Eddaoui, H. Ouchra and O. Hourrane, "A system for educational and vocational guidance in Morocco: Chatbot E-Orientation175," International Workshop on Artificial Intelligence \& Internet of Things (A2IoT), vol. 175, pp. 554-559, August 2020.

[13] Y. Kim and A. Baylor, "A social-cognitive framework for pedagogical agents as learning companions.," Educational technology research and development, vol. 54, no. 6, pp. 569-596, 2006 
[14] P. Bii, "Chatbot technology: A possible means of unlocking student potential to learn how to learn.," Educational Research, vol. 4, no. 2, pp. 218-221., 2013.

[15] S. Rodinadze and K. Zarbazoia, "The advantages of information technology in teaching English language.," Frontiers of Language and Teaching., vol. 3, no. 5, pp. 271-275., 2012.

[16] S. Pushpa, "Importance of English," in Tenth Annual Day Special Issue, 2018.

[17] P. Smutny and P. Schreiberova, "Chatbots for learning: A review of educational chatbots for the Facebook Messenger," Computers \& Education, vol. 151, pp. 1-11, 202.

[18] I. Yildirim, "The effects of gamification-based teaching practices on student achievement and students' attitudes toward lesson," The Internet and Higher Education, vol. 33, pp. 86 -92, 2017.

[19] M. Jain, P. Kumar, R. Kota and S. N. Patel, "Evaluating and Informing the Design of Chatbots," in Proceedings of the 2018 Designing Interactive Systems Conference, 2018.

[20] D. Braun and F. Matthes, "Towards a Framework for Classifying Chatbots," in Proceedings of the 21st International Conference on Enterprise Information Systems (ICEIS 2019), 2019.
[21] K. Y. Fang and H. Bjering, "Development of an interactive Messenger chatbot for medication and health supplement reminders," in 36th National Conference Health Information Management: Celebrating 70 years of Strength in Diversity, 2019.

[22] N. Haristiani, "Artificial Intelligence (AI) Chatbot as Language Learning Medium: An inquiry," in International Conference on Education, Science and Technology 2019, Padang, 2019.

[23] K. Widjajanti, M. Sarosa and M. Kusumawardhani, "Organizing Exercise Items in Mathematics Learning.," International Journal of Science and Research (IJSR), vol. 4, no. 5, pp. 2162-2167., 2015.

[24] P. Kostelník, I. Pisařovic, M. Muroň and F. Dařena, "Chatbots for Enterprises: Outlook," Acta Universitatis Agriculturae et Silviculturae Mendelianae Brunensis, vol. 67, no. 6, pp. 15411550., 2019.

[25] P. Smutny and P. Schreiberova, "Chatbots for learning: A review of educational chatbots for the Facebook Messenger," Computers \& Education, vol. 151, no. 1, p. 103862., 2020. 